\title{
Narcophobia Meets Queerphobia: Criminalisation, Harm Reduction and Responsibility in Polish Drug Policies
}

https://doi.org/10.51897/interalia/SPUM9550

\author{
Justyna Struzik \\ Jagiellonian University \\ ORCID: 0000-0003-3381-6180
}

In 2019, Sebastian Kaleta, a Polish parliamentarian associated with the ruling Law and Justice party, published a report denigrating Warsaw-based organisations working in the field of LGBT rights and harm reduction. The report allegedly shows what these organisations actually spend taxpayers' money on. ${ }^{1}$ In Kaleta's view, under the guise of working in the field of drug dependency and combating HIV/AIDS, the NGOs in fact "affirm" the use of psychoactive substances and "promote" nonheteronormative sexual behaviours. The distribution of condoms, education on how to use psychoactive substances in a safer way, de-stigmatisation of non-heteronormative sexual practices (e.g., chemsex), do, according to the author of the report, lead to the dissemination of "harmful ideologies," with so-called LGBT and gender ideologies at the forefront. The data used to create the report was public information published on the websites and social media networks of such organisations as Social Education Foundation (FES), which works in sex education and STIs prevention; Social Drug Policy Initiative (SIN), which organises screening tests of psychoactive substances and advocates for changing the public perception of drugs and drug laws in Poland; Sex Work Poland, which is an informal initiative of sex workers and allies advocating for sex workers' rights; Social Policy Foundation, PREKURSOR, a harm reduction organisation; and Social AIDS Committee (SKA) - HIV/ AIDS service provider. Nevertheless, the report was presented by the pro-government press as a document revealing the "hidden truth" and the "real face" of NGOs. What the document did was reinforce a logic already present in the Polish drug policy and the dominant way of thinking about drug use: only abstinence can be considered as the right state policy. Even if the state officially implements harm reduction programmes, measures that minimise harm in the field of non-heteronormative sexual practices, psychoactive substance use or sex work cannot be associated with "social deviance." According to this logic, citizens should not engage in risky behaviour, and if they do, all responsibility falls onto them. One of my research participants, who works with people who inject drugs, describes this logic by comparing the dominant narrative on drugs to the popular attitude towards sexuality expressed by policymakers:

I'm thinking of this kind of negation that people use..., not accepting the fact that people use [drugs - author's note] and have sex. It's such wishful thinking that

\footnotetext{
${ }^{1}$ It was not the first such voice by a state authority. More on harm reduction debates in Poland: Owczarzak, 2007, Struzik, 2021, Dziuban et al. 2021.
} 
everyone will stop using [drugs - author's note] and they won't use [drugs author's note] any longer. They won't have unprotected sex - it can be compared to that. It's nowhere near what most people do. This model is so drug-free and also it often negates pharmacology, or rather pharmacological support for treatment, to recover from addiction. The assumption here is that help and support are provided to those who choose abstinence, and those who choose to use... it doesn't really matter what happens to them, i.e. not only whether they have [drug-induced - author's note] collapse, but also whether they become infected with HIV or HCV.

Following various public discussions about illegal drugs, I have been wondering what the Polish drug wars bring to the common understanding of drug addiction. How do they produce, shift, reinforce or reject the meanings of such notions as responsibility, risk or vulnerability? How are drugs, drug use and drug users talked about and thought about in a society governed by restrictive drug laws, in a narcophobic society where harm reduction activities are still considered "morally controversial" (Malinowska-Sempruch, 2014)? To understand and unravel the "Polish drug wars" and their impact on the everyday functioning of harm reduction programmes, one has to look at the ways in which drugs, drug use and addiction are constructed in public discourse. Jarret Zigon (2019) writes about a certain fantasy world produced by the drug wars globally, a world that associates drugs with notions of addiction and addicts, but also with transgression, crime, and immorality. In order to fit into this fantasy, drug users, are socially constructed as internal enemies, as a threat, or as an enslaved population. Punishment, interestingly, can also be accompanied by concern. A person who uses psychoactive substances may, under certain circumstances, acquire the status of a "victim" of addiction who needs to be cared for, who needs to be helped to break free from drug use. Researchers refer to this strange yet pervasive combination of punishment and care as carceral care (Abbasi, 2020), which manifests itself not only at the level of discourse-fantasy worlds, but also at the level of policies and their concrete programs and solutions, and even more importantly, at the level of users' experiences. The wars on drugs across the globe share similar tropes, yet they take on different faces locally. These wars produce certain social images of what psychoactive substance use looks like, fabricating the subjectivities of drug users, and entangling them into the notions of vulnerability, risk, or responsibility.

Extensive scholarship on the harm reduction approach in different contexts indicates how these programmes often implement a logic that enforces the accountability of drug users who, through the implementation of successive tasks, are supposed to be able to re-shape their subjectivity - as responsible, rational, and productive citizens (and thus as useful to the state) (Moore, 2008; O'Malley and Valverde, 2004; Race, 2017). Locally, however, this logic can be shaped by a range of factors that alter the meanings attributed to harm reduction. My research shows how the criminalisation of the possession of psychoactive substances, on the one hand, and the abstinence-based model, on the other, have formed thinking about harm reduction in Poland as a solution that does not so much eliminate the problem but rather exacerbates it, as a solution that "absolves users of responsibility." 
Importantly, this particular narrative of harm reduction did not emerge in a social vacuum. The first harm reduction programmes in Poland were implemented in the 1990s, a period of rapid and dynamic political and economic transformation. The then ongoing transition to democracy and a neoliberal economy fabricated citizens primarily in terms of their economic utility and usefulness in sustaining a vision of a healthy, productive, and disciplined nation (Dunn, 2015). Echoes of such a vision could be heard during parliamentary discussions on the need for stricter drug laws at the end of the 1990s. During one session of the Polish parliament MP Henryk Kisielewski, in favour of criminalising the possession of psychoactive substances, said:

And since we talk so much in this Chamber from time to time about our belonging to the leading part of Europe, in which we want to take the position of subject, and not of object, not of a second-class state, let us enter it [the European Union author's note] as a strong nation, with a strong identity and moral value, let us be a healthy, strong and stable, and not a contaminated [by drug use - author's note] component of this newly shaping Europe ${ }^{2}$.

In addition, Catholic ideology was also strongly mobilised during this period - the Roman Catholic Church became an important political player, imposing ideas of abstinence and sobriety and conservative values. According to this vision, a responsible individual is one who demonstrates a strong will and moral purity and is able to reject pleasurable, yet "deviant," practices (Keinz, 2011). Parallel to the activities in the drug field, harm reduction activities also developed in the field of nonheteronormative sexuality and demanded the recognition of the rights of this group. The arguments put forward by opponents of a more liberal approach in these two areas (sometimes called "permissivism" in the media) were similar and reinforced each other.

Polish drug laws became more restrictive in the late 1990s. Political discussions at the time revealed ambivalent voices: criminalisation, although presented as a legitimate trend in drug policy, was to some extent resisted by some policymakers who saw opportunities for solving the "drug problem" in the need to introduce treatment and harm reduction programmes rather than in punishing people who use drugs (Malinowska-Sempruch, 2014; 2016). Importantly, however, approaches to psychoactive substance use since the 1980s have been dominated by the belief that total abstinence is the only valid solution to the drug problem. This model was pursued for years by the most influential organisation working in the drug field - MONAR (Youth Movement Against Drug Addiction). Abstinence and total rejection of psychoactive substances - ideas implemented in numerous stationary facilities across the country with a clear daily regime and community control - were supposed to teach people who use drugs responsibility for their own lives and give them the opportunity to demonstrate a strong will (Kotański, 1984; Dziuban et al., 2021). Thus, they were part of the carceral care approach: they offered care to people who use drugs, at the same time disciplining them and

\footnotetext{
2 The verbatim transcript of the sitting of 19.03 .1997 is available here: bs.sejm.gov.pl
} 
not accepting any form of rule transgression on their part (for some time, for example, relapse meant that MONAR patients could not be re-admitted to the facility again). Criminalisation of drug possession (now taken for granted by most politicians), introduced gradually since 1997, complemented the drug-free model. Over time, in the eyes of politicians, criminalisation started to be seen as a way to protect young people from the "massive and increasingly visible degradation" of drug use, and users themselves from death. ${ }^{3}$ New legal regulations, which were introduced just before and after Poland's accession to the EU in 2004, established a new figure in the social imagery of drugs, the drug user, previously defined in terms of a disease, who now became a criminal. Harm reduction, which was then in its infancy, did not fully fit into the emerging model of managing addicted bodies - it was perceived by policymakers rather as a tool for "deepening addiction" and weakening the chances of recovery (Dziuban et al., 2021). The slowly developing harm minimisation programmes (needle and syringe exchange programmes, substitution therapy, drop-ins) are only partially responsive to the needs of users (Bartnik and Kwiatkowska, 2015). The support offered in harm reduction programmes is often conditional - substitution programmes, for example, are based on a high-threshold model and a lack of trust in drug users. Patients are not allowed to use any psychoactive substances during their treatment, they are also subjected to unannounced urine tests for the presence of these substances, and for the first 6 months of treatment they must attend the treatment centre every day to collect methadone. This last rule can be relieved after six months of treatment, provided that the patient has not violated any of the rules of the facility. One interviewee described the support model for people with drug addiction as follows:

This is part of such a systemic destruction of this population, which has been going on for decades. This is a systemic extermination of addicts who do not want to take advantage of the abstinence offer, i.e. they continue to use and in their use they simply take this crap [poor quality drugs - author's note] and not the other; some switch to drinking. They do not stay in treatment because they drop out of treatment, but not because they want to drop out themselves, but because they get kicked out of treatment for taking substances.

People with drug dependency I interviewed during my research pointed out, for example, that substitution is still not available on prescription; in order to receive it, one has to join one of the substitution programmes located in one of the largest cities in Poland. Their functioning, however, is out of touch with the needs of patients, forcing them to travel frequently and to be regularly monitored by doctors. Quite recently, the dominant narcophobic narrative has been reinforced by the emergence of new psychoactive substances (so-called "legal highs"; in Polish dopalacze) on the drug market and has strengthened criminalising and punitive tendencies.

\footnotetext{
${ }^{3}$ In this context, the words "Better children in prison than in a cemetery" were spoken by the liberal politician Barbara Labuda, who expressed her support for the introduction of restrictive anti-drug laws. For a discussion of this approach see: Malinowska-Sempruch, 2014.
} 
Significantly, in contemporary political discourse, narcophobia and aversion to harm reduction meets queerphobia expressed in state actions. In recent years, we have observed a clear shift in the formation of homophobic public discourse in Poland. Representatives of the state often resort to homophobic arguments in order to mobilise such concepts as nation, healthy and functioning society and normality, and to use the concepts to manage society (Korolczuk, 2020). This shift is important because it reveals new dynamics in the relationship between the state and the citizen. A citizen who does not fit into the vision based on heteronormativity and productivity/usefulness becomes disposable for the state (Wang, 2018). Thus, there is no need to invest in harm reduction programmes.

In his report mentioned at the beginning of this text, Kaleta attacked above all those activities that go beyond the usual model of helping people who use drugs, the LGBTQ community and sex workers. What the report criticised were approaches that reject seeing these groups only in terms of their vulnerabilities, that consider the agency of individuals and groups and avoid disciplining them for transgressing socially accepted norms. In the Polish drug wars, responsibility is linked to abstinence; a responsible user is someone who stops taking drugs, accepting the logic reproduced by the state policy. Given the current political climate, the possibility of a shift in thinking about drug use, responsibility and users' subjectivity, remains unclear. However, campaigns denigrating the social action of organisations, implemented by those in power, encourage social mobilisation from below, leaving hope for new and more just drug policies.

This text is based on research conducted within the project CrimScapes: Navigating Citizenship through European Landscapes of Criminalisation, supported by a New Opportunities for Research Funding Agency Co-operation in Europe (NORFACE), Democratic Governance in a Turbulent Age (Governance) Joint Research Program, project no. 462-19-020.

\section{Works Cited}

Abbasi, Ghazah (2020), "Discipline and Commoditize: How U-Visas Exploit the Pain of GenderBased Violence", Feminist Criminology, 15.4: 464 -491. https://doi.org/10.1177/1557085120923037

Bartnik, Magdalena and Agata Kwiatkowska (2015), Iniekcyjni użytkownicy substancji psychoaktywnych [Injecting Users of Psychoactive Substances], Warszawa, Fundacja Redukcji Szkód.

Dunn, Elizabeth (2015), Privatizing Poland, Ithaca, NY, Cornell University Press. https://doi.org/10.7591/9781501702204

Dziuban, Agata, Friederike Faust, Todd Sekuler, Justyna Struzik, Lina Bonde and Emily J. Nicholls (2021), "HIV/AIDS and its Monsters: Negotiating Criminalisation along the Monster-Human Continuum", European Journal of Cultural Studies.

https://doi.org/10.1177/13675494211017911 
Keinz, Anika (2011), "European Desires and National Bedrooms? Negotiating 'Normalcy' in Postsocialist Poland", Central European History, 44.1: 92-117.

https://doi.org/10.1017/S0008938910001196

Korolczuk, Elżbieta (2020), "The Fight Against 'Gender' and 'LGBT Ideology': New Developments in Poland", European Journal of Politics and Gender, 3.1:165-167.

https://doi.org/10.1332/251510819X15744244471843

Kotański, Marek (1984), Ty zaraziteś ich narkomania [You Infected Them with Drug Addiction], Warszawa, Państwowy Zakład Wydawnictw Lekarskich.

Malinowska-Sempruch, Kasia (2014), HIV among Drug Users in Poland: The Paradoxes of an Epidemic, [Unpublished doctoral dissertation], Columbia University.

(2016), "Shaping Drug Policy in Poland". International Journal of Drug Policy, 31: 32-38.

https://doi.org/10.1016/j.drugpo.2016.02.018

Moore, David (2008), "Erasing Pleasure from Public Discourse on Illicit Drugs: On the Creation and Reproduction of an Absence", International Journal of Drug Policy, 19.5: 353-358.

https://doi.org/10.1016/j.drugpo.2007.07.004

O'Malley, Pat and Mariana Valverde (2004), "Pleasure, Freedom and Drugs: The Uses of Pleasure in Liberal Governance of Drug and Alcohol Consumption. Sociology, 38.1: 25-42. https://doi.org/10.1177/0038038504039359

Owczarzak, Jill Teresa (2007), Mapping HIV Prevention in Poland: Contested Citizenship and the Struggles for Health after Socialism. University of Kentucky Doctoral Dissertations. http://uknowledge.uky.edu/gradschool_diss/515.

Race, Kane (2008), "The Use of Pleasure in Harm Reduction: Perspectives from the History of Sexuality", International Journal of Drug Policy, 19.5: 417-23. https://doi.org/10.1016/j.drugpo.2007.08.008

(2017), "Thinking with Pleasure: Experimenting with Drugs and Drug Research", International Journal of Drug Policy, 49: 144-49. https://doi.org/10.1016/j.drugpo.2017.07.019

Struzik, Justyna (2021), "Citizenship and Pleasure: A Study on Harm Reduction Assemblages in Poland", Critical Public Health, 31.1: 30-42. https://doi.org/10.1080/09581596.2020.1849562

Wang, Jackie (2018), Carceral Capitalism, South Pasadena, Semiotext(e).

Zigon, Jarret (2019), A War on People: Drug User Politics and a New Ethics of Community, Oakland, California, University of California Press. 